\title{
Effectiveness of Algan Hemostatic Agent in Bleeding Control: An Experimental Kidney Incision Model
}

\section{Algan Hemostatik Ajanın Kanama Kontrolündeki Etkinliği: Deneysel Bir Böbrek insizyon Modeli}

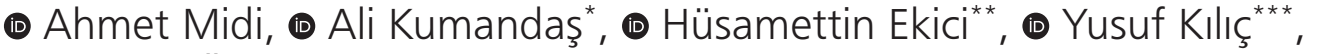 \\ (1) Ruchan Özgöçmen ${ }^{* * *}$ \\ Bahçeşehir University Faculty of Medicine, Department of Pathology, Istanbul, Turkey \\ *Kırıkkale University Faculty of Veterinary Medicine, Department of Surgery, Kırıkkale, Turkey

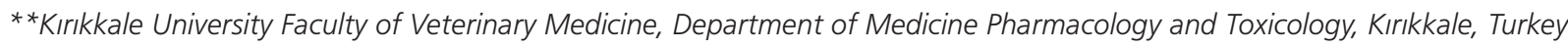 \\ *** University of Health Sciences Turkey, İstanbul Bakırköy Prof. Dr. Mazhar Osman Mental Health and Neurological Diseases Trahing \\ And Research Hospital, Clinic of Neurosurgery, Istanbul, Turkey \\ ****Bahçeşehir University Faculty of Medicine, Istanbul, Turkey
}

\section{Abstract}

Aim: The purpose of this study is to evaluate the hemostatic efficacy of a novel plant originated blood stopper which is called Algan Hemostatic Agent (AHA) in uncontrolled kidney incision bleeding model.

Methods: The study was conducted with thirty-two rats 5-7 weeks old. The rats were randomly divided into 4 groups, each consisting of eight rats (Group 1: heparinized saline, 2: heparinized AHA, 3: non-heparinized saline, 4: non-heparinized AHA). Experimental kidney incision was made, and saline soaked sponge was applied to the control group and AHA to the study group.

Results: The duration of bleeding was significantly shorter in the AHA group compared to the control group. The AHA has controlled the bleeding in the heparinized and non-heparinized groups $5 \pm 1.19$ and $3 \pm 0.91$ seconds respectively $(p<0.001)$. In the control group, hemorrhage was controlled in the heparinized and non-heparinized group $180.6 \pm 25.4$ and $125.4 \pm 21$ seconds respectively.

Conclusion: This study demonstrated that the AHA is useful in controlling bleeding in the Rat kidney incision model.

Keywords: Algan hemostatic agent, hemostasis, rats, kidney, bleeding
Öz

Amaç: Çalışmanın amacı Algan kanama durdurucu ajanın böbrek insizyon rat modelinde etkinliğini araştırmaktır.

Yöntemler: Çalışma 5-7 haftalık otuz iki sıçan ile yapıldı. Sıçanlar rastgele her biri sekiz sıçandan oluşan 4 gruba ayrıldı (Grup 1: heparinize salin, 2: heparinize AHA, 3: non-heparinize salin, 4: non-heparinize AHA). Deneysel böbrek insizyonu yapıldı ve kontrol grubuna salin emdirilmiş spanç, çalışma grubuna AHA uygulandı.

Bulgular: AHA grubunda kanama süresi kontrol grubuna göre anlamlı olarak daha kısaydı. AHA, heparinize ve heparinize olmayan gruplarda kanamayı sırasıyla $5 \pm 1,19$ ve $3 \pm 0,91$ saniyede kontrol etmiştir. Kontrol grubunda heparinize ve heparinize olmayan grupta kanama sırasıyla $180,6 \pm 25,4$ ve $125,4 \pm 21$ saniyede kontrol edildi.

Sonuç: Bu çalışma, AHA'nın sıçan parsiyel nefrektomi modelinde kanamayı kontrol etmede faydalı olduğunu göstermiştir.

Anahtar Sözcükler: Algan hemostatik ajan, hemostaz, sıçan, böbrek, kanama
Address for Correspondence/Yazışma Adresi: Ahmet Midi, Bahçeşehir University Faculty of Medicine, Department of Pathology, Istanbul, Turkey

Phone: +90 5333595661 E-mail: ahmetmidi@yahoo.com ORCID: orcid.org/0000-0002-6197-7654

Received/Geliş Tarihi: 29.08.2020 Accepted/Kabul Tarihi: 01.01.2021

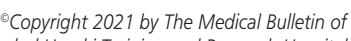
istanbul Haseki Training and Research Hospital The Medical Bulletin of Haseki published by Galenos Yayınevi.

${ }^{8}$ Telif Hakkı 2021 istanbul Haseki Eğitim ve Araştırma Hastanesi Haseki Tıp Bülteni, Galenos Yayınevi tarafından yayınlanmıştır. 


\section{Introduction}

Bleeding is one of the major complications of partial nephrectomy and there are some difficulties in providing homeostasis in surgical procedures. For this reason, many new techniques, tools and agents have been used in recent years to control bleeding in renal surgery during partial nephrectomy $(1,2)$.

The Algan Hemostatic Agent (AHA) is an herbal polysacrid-based extract derived from the standardized blend of six different plants $(3,4)$. Each of the plants that form AHA has a content which is effective in hemostasis by alone or in combination (5). AHA contains tannins, phenolic components, polysaccharide. It has been determined that the AHA contains $57 \%$ polysaccharides. In addition, the phenolic content of $50 \mathrm{mg} \mathrm{AHA} \mathrm{sample}$ was found to be equivalent to $3.015 \mathrm{mg} \mathrm{GAE} / \mathrm{g}$ (gallic acid). There are polysaccharide-based hemostats on the market. However, phenolic compounds have not been previously tested in bleeding control. This study is the first study in the control of bleeding in the kidney incision model of AHA in rats.

All biocompatibility tests such as sensitization, cytotoxicity and irritation and hemodynamic tests of the AHA were performed, and the results supported its safety and efficacy as a hemostatic agent. It was shown that AHA did not cause more damage on rat liver tissue than in the control in the hepatectomy, liver laceration skin wound models (6-8).

AHA is easily applied locally. Further, it has a low cost, and does not require special storage. When AHA used in moist environment, it quickly polymerizes into a thin elastic film which has high tensile strength and firmly adheres to the anatomy of the tissue on which it is applied. Today, there are many products used in bleeding control, and a product that can effectively control bleeding has not been produced yet $(9,10)$. The purpose of this study is to assess the hemostatic efficacy of the AHA kidney incision model.

\section{Methods}

This study was approved by the Institutional Animal Experiments Local Ethics Committee of Kırikkale University (number, 2018/07). All animal studies conformed to the animal experiment guidelines of the Committee for Humane Care. All animals received care in compliance with the "Principles of Laboratory Animal Care" formulated by the National Society for Medical Research and the "Guide for the Care and Use of Laboratory Animals" prepared by the US National Academy of Sciences and published by the US National Institute of Health (NIH Publications, No: 80-23).

In the literature, the kidney incision method has not been used, but in this study, the effectiveness was evaluated according to the partial nephrectomy model (11). Thirtytwo 180-210 gram 5-7-week-old Sprague Dawley rats were included in this study. Rats were fed ad libitum and examined under standard laboratory conditions according to a 12-hour dark-light period. The rats were randomly divided into 2 groups as heparinized and non-heparinized; each of the group has 16 rats. The rats were then randomly selected and divided into 4 groups of 8 rats in each group. Dose of $640 \mathrm{IU} / \mathrm{kg}$ heparin was administered intraperitoneal to heparinized group three times a day for 3 days. The same amount of saline was given to the other group. The groups were formed as follows. $1^{\text {st }}$ group (Heparinized control group), $2^{\text {nd }}$ group (Heparinized AHA liquid group), $3^{\text {rd }}$ group (Non-Heparinized control group), $4^{\text {th }}$ group (Non-Heparinized AHA liquid group. Procedures were performed under general anesthesia with ketamine hydrochloride $(100 \mathrm{mg} / \mathrm{kg})$ and xylazine hydrochloride (10 $\mathrm{mg} / \mathrm{kg}$ ).

\section{Rat Kidney Incision Model}

All operations will be performed under anesthesia. The renal artery and venous hilum were determined by vascular dissection for each rat. The renal artery and vein were not compressed with a vascular clamp. Deep incision was made in the lower third of the left kidneys with an amputation knife, and then AHA and saline were applied to the groups.

Partial nephrectomy models have been used in the literature. In this study, we used the kidney incision method. Considering the difficulty of applying AHA in partial nephrectomy, we made an incision. In this way, more contact with the bleeding surfaces in the area where AHA was applied was provided.

\section{Bleeding Test}

The kidneys of rats were surgically exposed and, the left kidney was resected from the lower pit (Figures 1, 2).

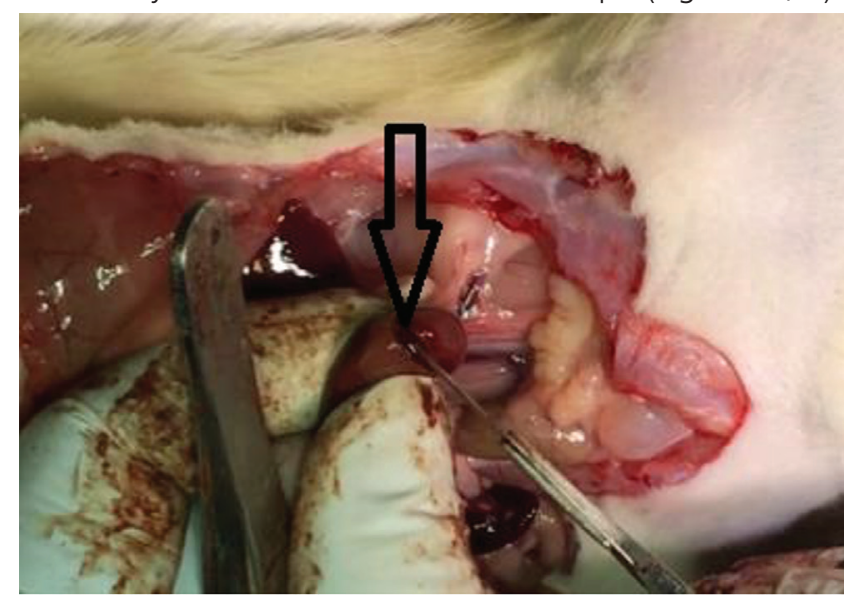

Figure 1. Application of kidney incision 
Immediately after the bleeding started, the first blood was cleaned with a dry sponge and the area was treated with 2 cc volumes of AHA liquid and $2 \mathrm{cc}$ saline. AHA liquid and saline were applied on the bleeding surface. Bleeding time was measured by chronometer. After stopping the bleeding (at the earliest 10 minutes after the end of the experiment) rats were euthanized by high intra-abdominal bleeding.

\section{Statistical Analysis}

SPSS software version 22.0 (SPSS Inc., Chicago, IL) was used to analyze the data of this study. Weights, bleeding time was calculated and was compared among the four groups using analysis of variance (ANOVA). When differences were found, the difference group was determined by Duncan's multiple range tests. The results were assessed at a 95\% confidence interval and a significance level of $p<0.05$.

\section{Results}

There was no difference in body weight between the groups. The duration of bleeding in the control group was longer than in the experimental groups.

The AHA liquid form has controlled the bleeding in the heparinized and non-heparinized groups $5 \pm 1.19$ and $3 \pm 0.91$ seconds respectively. In the control group, hemorrhage was controlled in the heparinized group at $180.6 \pm 25.4$ and in the non-heparinized group at $125.4 \pm$ 21 seconds. There was a statistically significant difference in bleeding control efficacy of the AHA compared to the control group (Table 1). AHA contributes to bleeding

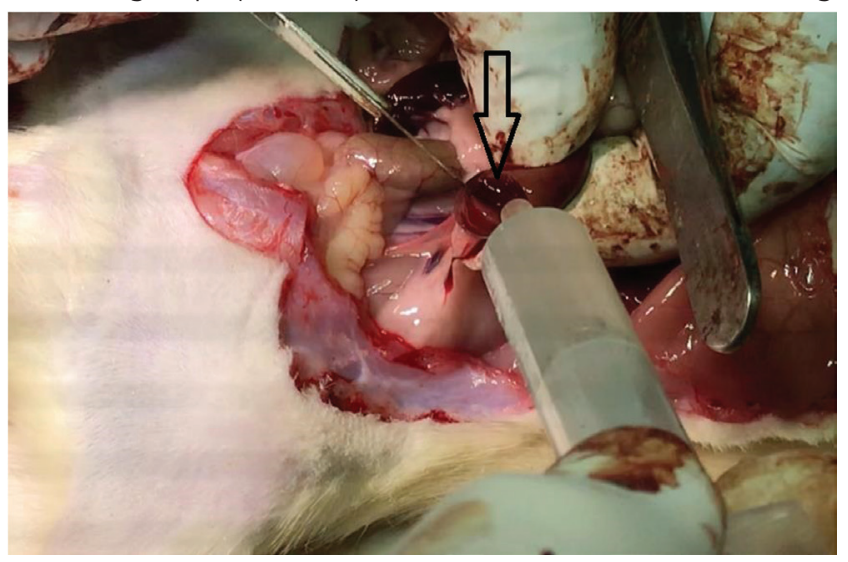

Figure 2. Application of the AHA liquid form AHA: American Hispital Association

\begin{tabular}{|c|c|c|}
\hline & $\begin{array}{l}\text { Group } 1 \\
\text { (Heparinized Control) }\end{array}$ & $\begin{array}{l}\text { Group } 2 \\
\text { (Heparinized } A H A)\end{array}$ \\
\hline Weight (grams) & $190.6 \pm 5.5$ & $189.5 \pm 7.3$ \\
\hline Bleeding time (sec.) & $180.6 \pm 25.4 \mathrm{sec}$ & $5 \pm 1.19 \mathrm{sec}$. \\
\hline
\end{tabular}

control by creating a mechanical barrier where it is applied (Figure 3).

\section{Discussion}

AHA had rapidly controlled bleeding in the kidney incision bleeding model. AHA liquid form stopped the bleeding in the first application both the heparin and nonheparinized group.

There was a statistically significant difference in the bleeding control efficacy of the AHA compared to the control group. These results have shown that AHA is a highly effective product in controlling bleeding.

Today, many hemostatic agents are used for internal and external bleeding control (9-17). In addition, cyanoacrylates are used safely in many clinical urology fields (18).

Traditionally, some plants are known to be used as bleeding arrestors. The mechanism of hemostatic action of these plants is based more on the astringency nature of the more common type of polyphenolic phytochemicals. Astringent, any of a group of substances that cause the contraction or shrinkage of tissues and that dry up secretions. However, some hemostatic plants have been shown to shorten the coagulation time and increase the coagulation of platelets in the area of bleeding, reducing the risk of infection and inflammation that can lead to infiltration and damage to vessels (19).

There are a lot of literature studies about AHA content plants (5). It has been shown that Polyphenolicpolysaccharide conjugates in the combination of Achillea millefolium and some Asteraceae plants have protective effects against oxidative damage on blood platelet proteins (20). Juglans regia L. contains tannin and leaves

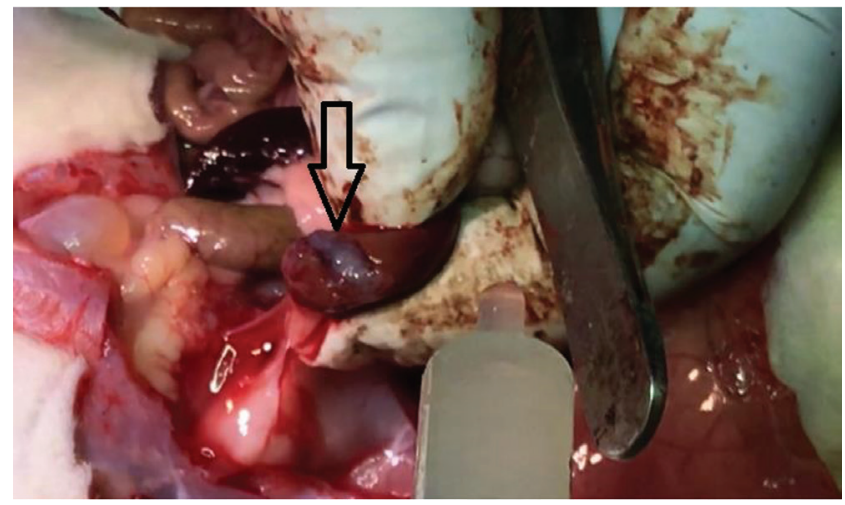

Figure 3. Barrier formation of the AHA application

\begin{tabular}{|l|l|l|}
$\begin{array}{l}\text { Group 3 } \\
\text { (Non-Heparinized Control) }\end{array}$ & $\begin{array}{l}\text { Group 4 } \\
\text { (Non-Heparinized AHA) }\end{array}$ & p \\
\hline $175.6 \pm 10.5$ & $182.4 \pm 7.5$ & $p=0.94$ \\
\hline $125.4 \pm 21.2 \mathrm{sec}$. & $3 \pm 0.91 \mathrm{sec}$. & $p<0.001$ \\
\hline
\end{tabular}


are used as astringent in external bleeds. Tannins cross-link with damaged cells to accelerate healing (21).

Rubus coreanus in the AHA formulation has antiaggressive activity. This plant can also play a role in preventing the formation of platelets by common organic acids, resulting in systemic clogging of vessels due to excessive clotting $(22,23)$. Rubus coreanus in the AHA has antithrombotic activity and is important for the prevention of systemic thrombotic effect against the possibility of systemic circulation of AHA after topical application. It shows the AHA effect locally by creating a physical barrier. The blood outside the vein forms a physical barrier by forming a polymeric network after the AHA is in contact with the fluid $(5,6)$. The blood clotted in this polymeric network rapidly solidifies with the clotting enhancing effect of AHA and the physical effect soon becomes a permanent barrier. In the event of possible systemic circulation, the systemic aggravating effect is eliminated by the anti-agonist effect of Rubus coreanus.

Viscum album L. Leaves of the plant (Herba Visci albi) are used for internal bleeds and many purposes. No adverse effects were observed in acute, subchronic and genotoxicity tests (24).

The amount of tannin from Vitis vinifera $L$. leaves is high and infusion (5\%) is used as an astringent and bloodblocker; fresh leaves are used externally as wound healers (25).

AHA was obtained by brewing from a standard mixture of six different plants. AHA biocompatibility tests were conducted and converted into the final product. AHA is produced in many forms such as liquid, powder and sponge $(3,4,6,7,26)$.

However, AHA has an easy-to-apply feature, as well as an advantage over other products in terms of hemostasis in a much shorter time.

There are few studies in the literature investigating the efficacy of hemostatic agents in the nephrectomy model. In one study, Glubran2 ${ }^{\circledR}$, FloSeal ${ }^{\circledR}$, and Celox ${ }^{\mathrm{TM}}$ were compared in rats with partial nephrectomy hemostatic efficacy (12). In this study hemostasis time was found to be $32,40,55$ seconds.

In another study, after partial nephrectomy, the mean bleeding time with BloodSTOP iX and Surgicel treatment was found $83.70 \pm 13.73$ seconds and 168.8 \pm 19.41 seconds, respectively (27).

In another study, it was shown that local hemostatic agent shortens the nephrectomy time (28). All the forms of the AHA differ greatly from these results. Because of the many factors such as animal weight, the experience of the practitioner, technical differences, vessel variations, laboratory conditions, etc., this comparison needs to be compared with other products in the same experiment to assess bleeding effectiveness of other bleeding arrestors.

\section{Limitations of the Study}

A limitation of this study is that only the acute stage effects of the AHA are assessed.

The fact that histopathological effects have not been investigated is a cause of limitation. The difference in the amount of bleeding between rats is one of the other limitations of this study.

In addition, the method used in this study is not a standard method used in the literature and may need to be improved.

\section{Conclusion}

This study has shown that AHA is a candidate for use as an effective product in hemostasis in nephrectomy operations. According to the results of this study, although AHA is the effective hemostatic agent available in the kidney incision bleeding, the actual difference can only be demonstrated by comparative studies. This situation will be clearer with future work.

The advantages of AHA when compared with other products that are readily available include effectiveness, ease of application.

\section{Authorship Contributions}

Concept: A.M., A.K., H.E., Design: A.M., A.K., H.E., Data Collection or Processing: A.M., A.K., H.E., Y.K., Analysis or Interpretation: A.M., Y.K., R.Ö., Literature Search: A.M., Y.K., R.Ö., Writing: A.M., Y.K., R.Ö.

Conflict of Interest: No conflict of interest was declared by the authors.

Financial Disclosure: This study supported by The Algan Group Health Services (Algan Group Health Services Import and Export Industry and Trade Limited Company, Istanbul, Turkey). The company had been role of the study materials provided for scientists, but had no role in study design, data collection and analysis, decision to publish, or preparation of the manuscript.

\section{References}

1. Kommu SS, McArthur R, Emara AM, et al. Current Status of Hemostatic Agents and Sealants in Urologic Surgical Practice. Rev Urol 2015;17:150-9.

2. Breda A, Stepanian SV, Lam JS, et al. Use of haemostatic agents and glues during laparoscopic partial nephrectomy: a multi-institutional survey from the United States and Europe of 1347 cases. Eur Urol 2007;52:798-803.

3. Midi A, Kumandaş $A$, Ekici $H$, et al. Investigation of the effectiveness of algan hemostatic agent in renal venous bleeding model in rats. EJMI 2018;2:129-32. 
4. Midi A, Ekici $H$, Kumandas $A$, et al. Investigation of the effectiveness of algan hemostatic agent in bleeding control using an experimental partial splenectomy model in rats. Marmara Medical Journal 2019;32:27-32.

5. Yeşilada E, Sezik E, Honda G, Takaishi Y, Takeda Y, Tanaka T. Traditional medicine in Turkey IX: folk medicine in north-west Anatolia. J Ethnopharmacol 1999;64:195-210.

6. Midi A, Kumandas A, Ekici $H$, et al. Investigation of the Efficacy of Algan Hemostatic Agent in Liver Laceration Model in Rats. EJMO 2019;3:37-42.

7. Midi A, Ozyurek HE, Karahan S, et al. Investigation of efficacy of the plant based Algan hemostatic agent in hepatectomy bleeding model in rats. EJMI 2018;2:195-201.

8. Aksoy $H$, Sener A, Akakin D., et al. The Effect of algan hemostatic agent (AHA) on wound healing. Clinical and Experimental Health Sciences 2020;10:279-84.

9. Huri E, Beyazit Y, Mammadov R, et al. Generation of Chimeric "ABS Nanohemostat" Complex and Comparing Its Histomorphological In Vivo Effects to the Traditional Ankaferd Hemostat in Controlled Experimental Partial Nephrectomy Model. Int J Biomater 2013;2013:949460.

10. Chiara O, Cimbanassi S, Bellanova G, et al. A systematic review on the use of topical hemostats in trauma and emergency surgery. BMC Surg 2018;18:68.

11. Slezak $P_{1}$ Heher $P$, Monforte $X$, et al. Efficacy of Topical Hemostatic Agents: A Comparative Evaluation of Two Gelatin/Thrombin-Based Hemostatic Matrices in a Porcine Kidney Surgical Model. J Invest Surg 2019;32:646-53.

12. Yucel $\mathrm{MO}$, Polat $\mathrm{H}$, Bagcioglu $\mathrm{M}$, et al. Comparison of the efficacy and histopathological effects of three hemostatic agents in a partial nephrectomy rat model. Int Urol Nephrol 2016;48:65-71.

13. Ebrahimi F, Torbati M, Mahmoudi J, Valizadeh H. Medicinal Plants as Potential Hemostatic Agents. J Pharm Pharm Sci 2020;23:10-23.

14. Pacheco M, Barros AA, Aroso IM, et al. Use of hemostatic agents for surgical bleeding in laparoscopic partial nephrectomy: Biomaterials perspective. J Biomed Mater Res B Appl Biomater 2020;108:3099-123.

15. Durant AM, Lehman E, Robyak H, Merrill SB, Kaag MG, Raman JD. Hemostatic agent use during partial nephrectomy: trends, outcomes, and associated costs. Int Urol Nephrol 2020;52:2073-8.

16. Carrion DM, Y Gregorio SA, Rivas JG, Bazán AA, Sebastián $J D$, Martínez-Piñeiro L. The role of hemostatic agents in preventing complications in laparoscopic partial nephrectomy. Cent European J Urol 2017;70:362-7.

17. Aykan S, Temiz MZ, Ulus I, Yilmaz M, Gonultas S, Suzan S, Semercioz A, Muslumanoglu AY. The Use of Three Different Hemostatic Agents during Laparoscopic Partial Nephrectomy: A Comparison of Surgical and Early Renal Functional Outcomes. Eurasian J Med 2019;51:160-4.

18. Ayyıldız SN, Ayyıldız A. Cyanoacrylic tissue glues: Biochemical properties and their usage in urology. Turk J Urol 2017;43:1424.

19. Colman RW, Clowes AW, George JN et al., Overview of hemostasis. (Eds. Colman, Clowes, George)

20. "Hemostasis and Thrombosis: Basic Principles and Clinical Practice". 5. edition, Lippincott, Williams\&Wilkins, Philadelphia, 2006; p.1-16.

21. PDR, 2002. Physicians' Desk Reference for Herbal Medicine. Editor: Gruenwald J., Brendler T., Jaenicke C., Thomson Co., 2nd Edition.

22. Dudzinska D, Bednarska K, Boncler M, Luzak B, Watala C. The influence of Rubus idaeus and Rubus caesius leaf extracts on platelet aggregation in whole blood. Cross-talk of platelets and neutrophils. Platelets 2016;27:433-9.

23. Han N, Gu Y, Ye C, Cao Y, Liu Z, Yin J. Antithrombotic activity of fractions and components obtained from raspberry leaves (Rubus chingii). Food Chem 2012;132:181-5.

24. Mengs U., 1998. Toxicity of an aqueous mistletoe extract: Acute and subchronic toxicity in rats. Genotoxicity in vitro. Ed.: Bardocz et al., "Effects of antinutrients on the nutritional value of legume diets. European Commission, Luxembourg.

25. Nees S, Weiss DR, Reichenbach-Klinke E, et al. Protective effects of flavonoids contained in the red vine leaf on venular endothelium against the attack of activated blood components in vitro. Arzneimittelforschung 2003;53:330-41.

26. Gedar Totuk ÖM, Güzel ŞE, Ekici H, et al. Effects of Algan Hemostatic Agent on bleeding time in a rat tail hemorrhage model. Ulus Travma Acil Cerrahi Derg 2020;26:853-85.

27. Ferretti L, Qiu X, Villalta J, Lin G. Efficacy of BloodSTOP iX, surgicel, and gelfoam in rat models of active bleeding from partial nephrectomy and aortic needle injury. Urology 2012;80:1161-6.

28. Huri E, Akgül T, Ayyildiz A, Ustün H, Germiyanoğlu C. Hemostatic role of a folkloric medicinal plant extract in a rat partial nephrectomy model: controlled experimental trial. J Urol 2009; 181:2349-54. 